\title{
Resource-Based View (RBV) of Unincorporated Social Economy Organizations
}

\author{
Kunle Akingbola
}

\author{
Lakehead University
}

\begin{abstract}
This article examines three related questions about unincorporated social economy organizations (USEOs): What are the characteristics of these social economy organizations? What is the unique bundle of resources that gives rise to and sustains their operations? Is there evidence of bricolage in these organizations? The findings suggest that USEOs are driven foremost by a social mission. USEOs provide diverse services and products including economic and specialized social activities, which are integral to the social fabric of society. The results also show that they combine and leverage two core resources - social capital and human capital to support the operations of their organizations. Moreover they appear to draw on whatever resources are at their disposal to support the activities of the organization. This suggests that USEOs are involved in bricolage activities, which could explain the longevity of many of the organizations.
\end{abstract}

\section{RÉSUMÉ}

Cet article répond à trois questions étroitement liées sur les organismes d'économie sociale non constitués en société : Quelles sont les caractéristiques de ces organismes? Quelles sont les ressources particulières qui leur permettent de fonctionner? Ces organismes ont-ils recours au bricolage (dans le sens que Claude Lévi-Strauss prête à ce mot)? Les résultats indiquent qu'une mission sociale est ce qui motive les organismes d'économie sociale non enregistrés. Ces derniers fournissent une diversité de produits et services, y compris des activités économiques et sociales spécialisées qui sont essentielles pour la solidarité sociale. Les résultats montrent aussi que ces organismes combinent deux ressources clés - le capital social et le capital humain - afin d'appuyer le bon fonctionnement de leurs organisations. En outre, pour ce faire, ils ont apparemment recours à toute ressource qui soit à leur portée. Cette dernière pratique indique que les organismes d'économie sociale non constitués en société mènent vraisemblablement des activités de bricolage, ce qui pourrait expliquer pourquoi bon nombre de leurs organisations ont si longue vie.

\section{Keywords / Mots clés}

Unincorporated; Social economy; Resource-based view; Bricolage / Non enregistré; Économie sociale; Théorie des ressources; Bricolage 


\section{Akingbola (2013)}

\section{INTRODUCTION}

It is important to recognize that most organizations are simply legal fictions which serve as a nexus for a set of contracting relationship among individuals. This includes firms, non-profit institutions such as universities, hospitals and foundations, mutual organizations such as mutual savings banks and insurance companies and co-operatives, some private clubs and even government bodies such as cities, states and the Federal government, government enterprises such as TVA, the Post Office, transit systems, etc. (Jensen \& Meckling, 1976, p. 8)

Organizations are an enigma of modern society. Not only are we amazed and intrigued by what they are, what they do, and how they change, we continue to try to understand how they are different. The interest in organizational heterogeneity and how new forms of organizations emerge, has preoccupied scholars in different fields of study (Castells \& Portes, 1989; Jepperson \& Meyer, 1991; Schneiberg, 2002). While there are critiques (see Carroll, 1993), one of the ways organizational theorists tend to explain differences between organizations is the diversity of the environments and the unique bundle of resources they are able to put together (Hannan \& Freeman, 1977; Oliver, 1997; Scott, 1987). Through institutional instruments such as the legal system, society grants legitimacy and provides access to resources that facilitate organizations. Hence, it has been suggested that the extent of diversity of organizations and the ability to create new organizations, vary between societies (Jepperson \& Meyer, 1991). However, research interests in management studies have largely omitted organizations below the radar of legal incorporation or registration (Godfrey, 2011), such as unincorporated social economy organizations (USEOs).

USEOs are organizations that are not formally registered or incorporated under a legal regime. Essentially, they are part of the informal economy, which "is unregulated by the institutions of society, in a legal and social environment in which similar activities are regulated" (Castells \& Portes, 1989, p. 12). Examples include farmers markets, sports and recreation associations, and advocacy groups. Research on these social economy organizations, which fall within the cracks of the legal institutions of society, is particularly lacking. We know very little about the estimated tens of thousands of unincorporated organizations that contribute to the economic and social health of Canada.

This article draws on a resource-based view (RBV; Barney, 1991; Wernerfelt, 1984) and the concept of bricolage (Levi-Strauss, 1968) to examine USEOs. It addresses three related questions: What are the characteristics and challenges of this organizational form? What is the unique bundle of resources that gives rise to and sustains the operations of these organizations? Is there evidence of bricolage in these organizations? This study is predicated on the need to understand and learn from organizations that straddle the space between business firms and nonprofits in their activities and operate outside the legal system of regulation in society. RBV is a particularly rich framework for analyzing the activities of USEOs because of its focus on the characteristics of resources, and how an organization deploys its resources. RBV proposes that the capability of an organization to acquire, develop, combine, and effectively deploy its physical, human, and organizational resources provides critical value and competitive advantage (Barney, 1991; Wernerfelt, 1984). Elsewhere, Oliver (1997) has extended the RBV, proposing that both resources and the institutional context of resources influence how an organization creates value and organizational heterogeneity.

The concept of bricolage has been defined "as making do by applying combinations of the resources at hand to new problems and opportunities" (Baker \& Nelson, 2005, p. 333). Fundamentally, bricolage has been used to explain the process through which individuals acquire, accumulate, and combine available resources and 
deploy whatever strategies are required to achieve different ends, and/or to adapt to existing situations ( $\mathrm{Di}$ Domenico, Haugh, \& Tracey, 2010). They noted that the concept emphasizes resourcefulness in action under various circumstances. The importance of the social context of resources and capabilities evidenced in RBV and the concept of bricolage underlie this research.

While the core idea of RBV was developed to examine firms (for-profit organizations) and firm heterogeneity in terms of competitive advantage, the theory is particularly relevant to the context of social economy organizations for three reasons. First, the focus on resources and on decision-making regarding the allocation of resources to gain competitive advantage is consistent with the characteristics of, and interactions that underlie social economy organizations. Following Barney (1991), this article posits that the creation, growth, and sustainability of social purpose ventures depend to a large extent on their ability to acquire and effectively combine resources that are difficult to imitate. Second, RBV posits that resources and capabilities which are socially complex, are likely to be sources of sustained heterogeneity (Barney, 1995). As explained below, socially complex resources and capabilities tend to be an important paradigm in the activities of social economy organizations. Moreover, the question of how these create sustained heterogeneity is central to strategic management in the sector. Third, RBV has been applied to examine factors that shape human resource management in nonprofit organizations, a major type of social economy organization (Akingbola, 2012; Ridder, McCandless Baluch, \& Piening, 2012). Thus, RBV's emphasis on resources is important in the analysis of the core resource of these organizations. Although this article draws on an entrepreneurial process framework in RBV to examine the resources of USEOs, this article is not about social enterprise or entrepreneurship.

The article proceeds as follows. After a discussion of the domain of USEOs, the next section presents the theoretical framework that draws on RBV to analyze the context of USEOs. This is followed by the methodology used for the study. The subsequent section presents the empirical findings with analysis. Finally, a discussion of the implications for research and practice is provided.

\section{UNINCORPORATED SOCIAL ECONOMY ORGANIZATIONS}

The domain of USEOs stretches the imagination of what is an organization. This is why it is logical to explain the boundaries by offering the definition of the two concepts that capture the characteristics of the organizations. The two concepts are: social economy and informal economy. Following Quarter, Mook, and Armstrong (2009), social economy is a bridging concept for organizations that have social objectives central to their mission and their practice, and either have explicit economic objectives or generate some economic value through the services they provide and purchases that they undertake. Basically, social economy organizations include different types of nonprofits and cooperatives that emphasize social mission, manifest social objectives in their practices, and can generate economic value (Mook, Quarter, \& Ryan, 2010). To understand social economy organizations, one must recognize the core functions of their activities. Social economy organizations perform three main functions (Enjorlas, 2010). First, they perform a solidarity function by providing a social space outside of the market, the state, or the family, for individuals to participate voluntarily in reciprocal exchanges. Second, social economy organizations perform a democratic function. They offer individuals the opportunity for direct or participatory democracy unlike the representative democracy of modern government. Finally, they perform a productive function. Enjolras (2010) notes that social economy organizations perform productive functions that are different from for-profit organizations and the government because of the unique dimensions that characterize their production of services. The functions of social economy organizations are built on a foundation of common interests and shared values that reflect the characteristics of the context (Bouchard, 2010) such as the identities or orientation of stakeholders, and the space unoccupied by government and forprofit organizations. 


\section{Akingbola (2013)}

In addition to operating in the social economy, the organizations in this study are also part of the informal economy. While many social economy organizations operate within the formal economy and under institutional regulation, unincorporated organizations are outside of the formal economy. The main characteristic of the informal economy is that it is "unregulated by the institutions of society, in a legal and social environment in which similar activities are regulated" (Castells \& Portes, 1989, p. 12). Castells and Portes posit that the informal economy exists because there is a formal economy. They contend that regulation creates the difference between formal and informal economies and that if there is no regulation of any kind, all economic activities will be classified as informal. French theorists have consistently recognized informal organizations with social objectives as part of the social economy (Laville, Bélanger, Boucher, \& Lévesque, 1994; Vienney, 1994). Specifically, Laville et al. (1994) characterize organizations in the social economy as "community groups, intermediaries between the anonymous collectivity and the family, ... places likely to foster real and free solidarity, to which many people aspire" (p. 208). This perspective is evident in the classification of practices associated with the informal economy as part of the social economy (Quarter et al., 2009). In line with Godfrey (2011), consideration of USEOs in this article proposes that the informal status is "based on conscious valuesdriven criteria rather than economic necessity or advantage" (p. 235). However, it is relevant to note that the informal economy also includes actors and organizations operating with an upfront organization but excludes domestic and illegal activities (Godfrey, 2011).

Social relations, networks, institutionalized power relationships, and the access to resources that come with them, could influence the ability and interest of actors to create formal or informal organizational forms (Stinchcombe, 1965). Thus, actors who prefer not to play within institutionalized regulations need to learn about alternatives, possess resources to leverage, and power to resist entrenched interests in order to create new organizational forms (Schneiberg, 2002). Following this line of argument, whether an organization is in the formal or informal economy could depend on the willingness and ability of actors to operate, source, and acquire resources within the system of institutionalized regulation. As explained in the next section, the question of access to resources is particularly important in USEOs not only because they operate in the informal economy but also in terms of their social economy paradigm. Thus, understanding the characteristics of USEOs and the resource bases that support their activities is important because the characteristics and context of incorporated organizations may not apply.

\section{THEORETICAL FRAMEWORK}

The fundamental construct of RBV and the concept of bricolage are central to the question of resources. From the perspective of RBV, organizations are heterogeneous bundles of idiosyncratic, hard-to-imitate resources and capabilities (Thornhill \& Amit, 2003). Organizations are made up of diverse resources and capabilities, which they require to function and achieve competitive advantage. Hence, the focus of RBV is the characteristics of the resources and capabilities of organizations (Amit \& Schoemaker, 1993; Barney, 1986,1991; Wernerfelt, 1984). Scholars posit that RBV explains how organizations develop, combine, and deploy resources and capabilities to achieve above average returns and competitive advantage. While having resources and capabilities is important, it does not necessarily determine competitive advantage and organizational heterogeneity. What is critical in order to achieve sustainable competitive advantage, are the rational decisions on which valuable, rare, and difficult to copy resources to use, and how to use them (Barney, 1991).

Oliver (1997) proposes that the acquisition and use of resources and capabilities is not only mediated by strategic market factors, but also by the social context within which decisions are made. Oliver argues that the institutional context significantly impacts resources, how they are selected and the competitive advantage 


\section{Akingbola (2013)}

outcome of the process. She categorizes three levels of institutional context: individual, firm, and inter-firm. The individual level is characterized by norms and values of decision makers. The focus of the firm level is organizational culture and politics. The inter-firm level includes public and regulatory pressures and industrywide norms. The social context at the firm level mediates the procurement and optimal use of resources.

This social context of resources and capabilities is evidenced in the entrepreneurship paradigm of RBV. The entrepreneurship perspective of RBV considers the sourcing of appropriate resources and the ability to combine them as the key to building a new venture (Alvarez \& Busenitz, 2001; Conner, 1991). Thus, the focus on how resources are sourced, acquired, and deployed by entrepreneurs to create new opportunities is intended to explain entrepreneurial ability as a distinct resource. The key question for this perspective is: where do resources come from (Rasmussen, Mosey, \& Wright, 2011)?

Similarly, the acquisition, combination, and use of resources are at the core of the concept of bricolage introduced by Levi-Strauss (1968). However, bricolage is premised on the idea that whatever resource is at hand could be deployed for new purposes, opportunities, or for future use (Baker \& Nelson, 2005; Di Domenico et al., 2010; Levi-Strauss, 1968; Soteri-Proctor, 2011). Therefore, for the bricoleur (the individual engaged in bricolage), what is important is "always to make do with 'whatever is at hand' " (Levi-Strauss, 1968, p. 17). In a way, bricolage is about non-selective resource maximization in that it emphasizes a pragmatic approach in the use and reuse of resources. As noted above, Baker and Nelson (2005) define bricolage "as making do by applying combinations of the resources at hand to new problems and opportunities" (p. 333). They note that this definition incorporates Levi-Straus' (1968) original construct and prior literature on bricolage. Baker and Nelson (2005), outline three elements of their definition: making do; combining resources for new purposes; and resources at hand. They explain that "making do" suggests a preference for action and being immersed in the problems or opportunities, while "combination of resources for new purposes" describes how resources are adapted and applied for different outcomes and uses. The construct of "resources at hand" speaks to the accumulation of resources such as skills, based "on the principle that "they may always come in handy" (LeviStrauss, 1968, p. 18).

Unlike prior conceptualizations of bricolage that suggest that actors refuse to test the limitations imposed by the institutionalized environment in order to see the possibilities (Weick, 1995), Baker and Nelson (2005) emphasize that bricolage includes actors' conscious attempt to test the resource limitations imposed upon them. They contended that actors put in substantial effort to resist the constraints of the system and refuse to see the resources they have as valueless. This, in effect, triggers a process of mix and match, trial and error, and intense creative combination of resources to make something out of nothing (Baker \& Nelson, 2005). This process is fundamental to bricolage.

In his case study of Olivetti, Ciborra (1996) found that strategy and outcomes are by-products of an implicit process involving pragmatic muddling practices rather than a laid out plan. Essentially, Ciborra found that managers work as "smart bricoleurs" by engaging in a collective process of trial and error of new organizational combination (Ciborra, 1996, p. 116). In this instance, bricolage is exemplified by the resourceful appropriation of existing organizational mechanisms and forms, that is, the recombination of existing resources for new purposes.

Although the concept of bricolage has been applied extensively in the literature (see Baker \& Nelson, 2005; Soteri-Proctor, 2011), the question of "making do by applying combinations of the resources at hand to new problems and opportunities" especially in the resource-poor environment illustrated by Baker and Nelson (2005), is particularly relevant to the context of USEOs. Moreover, the social characteristics of the organizations 


\section{Akingbola (2013)}

and the resource constraints imposed by their unincorporated status points to resource limitations entrenched in their institutional settings.

The closest application of the concept of bricolage in the social economy domain can be found in research that examines social entrepreneurs. According to Zahra, Gedajlovich, Neubaum, and Shulman, (2009), social bricoleurs are driven by the goal of addressing local social needs, within their area of expertise and which they could acquire resources to solve. They note that those social bricoleurs who work collectively to achieve such a social mission, have the ability to identify opportunities and translate small-scale local social opportunities into problem-solving organizations.

To investigate the resource base of USEOs, this article draws on Alvarez and Busenitz's (2001) construct of entrepreneurial recognition and process. They suggested that the process of entrepreneurship involves first, the awareness of opportunities, second, the ability to acquire the resources needed to exploit the opportunity, and finally, the organizational ability to recombine homogeneous inputs into heterogeneous outputs.

Consistent with this paradigm, this article proposes that USEOs are founded by social purpose entrepreneurs who follow a similar trajectory. However, since social economy organizations, whether incorporated or unincorporated, are established primarily to achieve social objectives (Quarter, 1992), the goal of the venture process is different. The social economy is a

[large] and diverse group of free, voluntary microeconomic entities created by civil society to meet and solve the needs of individuals, households and families rather than remunerate or provide cover to investors or capitalist companies ..., and is involved in a varied spectrum of activities, market and non-market, of mutual interest or of general interest. (Chaves \& Monzón Campos, 2007).

As a result, the social economy venture process involves three similar steps. First, there must be an "awareness of opportunities" to translate shared values into a problem-solving organization. Second, the ability to "source and acquire the resources" needed to solve mutual or general needs. Finally, the problem-solving organization must have the ability to "mobilize and combine homogeneous inputs into heterogeneous outputs."

Moreover, social economy organizations tend to have distinct resources and capabilities, which are a by-product of their social complexity. Research suggests that some of the competencies required to meet the complex organizational realities of the nonprofit type of social economy organizations are unique (Akingbola, 2006; Herman, 2004; O'Neill, 1998). Akingbola (2012) suggests that there are three distinct sources of resources and capabilities of nonprofits. First, are the "structural resources and capabilities," such as the human capital of volunteers, employees, and retained earnings that are derived from the nonprofit status of the organization. In the article, human capital emphasizes the strategic importance of the knowledge, skills, and capabilities of volunteer members and employees to an organization (Wright \& McMahan, 1992). Second, are the "institutional resources and capabilities," that are a by-product of the confluence of social, political, and economic relationships and the complex set of historical forces that give rise to nonprofits (Salamon \& Anheier, 1998). Through social interactions, nonprofits acquire, develop, and deploy competencies, social networks, and tangible assets to gain a competitive advantage. A key component of institutional resources is social capital, defined as the character and value of relationships within and outside the organization (Snell, 1999). Finally nonprofits have "values-based resources and capabilities," that differentiate the organization from the competition. Frumkin and Andre-Clark (2000) argue that the ability of nonprofits to emphasize the values-driven side of strategy over operational efficiency will result in sustainable competitive advantage. The values that 
constitute the core characteristic of nonprofits are a critical resource and source of capabilities that can be deployed to achieve the goals of the organization.

The capabilities of social economy organizations are embedded with competencies that are similar to those required to access resources in entrepreneurship. Rasmussen et al. (2011) identify three categories of entrepreneurial competencies that are important for nascent ventures to achieve credibility: opportunity refinement competency; leveraging competency; and, championing competency. The authors explain that "opportunity refinement competency" is the awareness of an opportunity and "the ability to further refine and develop the opportunity into a clearly articulated and commercially viable business concept" (p. 1327). "Leveraging competency" is the ability to source and acquire resources to build a venture, while "championing competency" is about the leadership ability needed to sustain the venture start-up process.

Figure 1 illustrates the relationship between social economy venture process, categories of entrepreneurial competencies, and the distinct resources and capabilities of social economy organizations. Together, these concepts underlie the central questions of this research: What are the characteristics of USEOs? What resources are critical to the USEOS? How do the organizations acquire and combine the resources they require to function? Due to the informal characteristic of these organizations, little is known about their scale, dimension, or operations. An understanding of the resource base and how USEOs use inputs to create value for mutual and / or general interest is necessary in order to begin to investigate strategic management practices and lay a foundation for research to map the sector.

\section{Figure 1: Unincorporated social economy venture process}

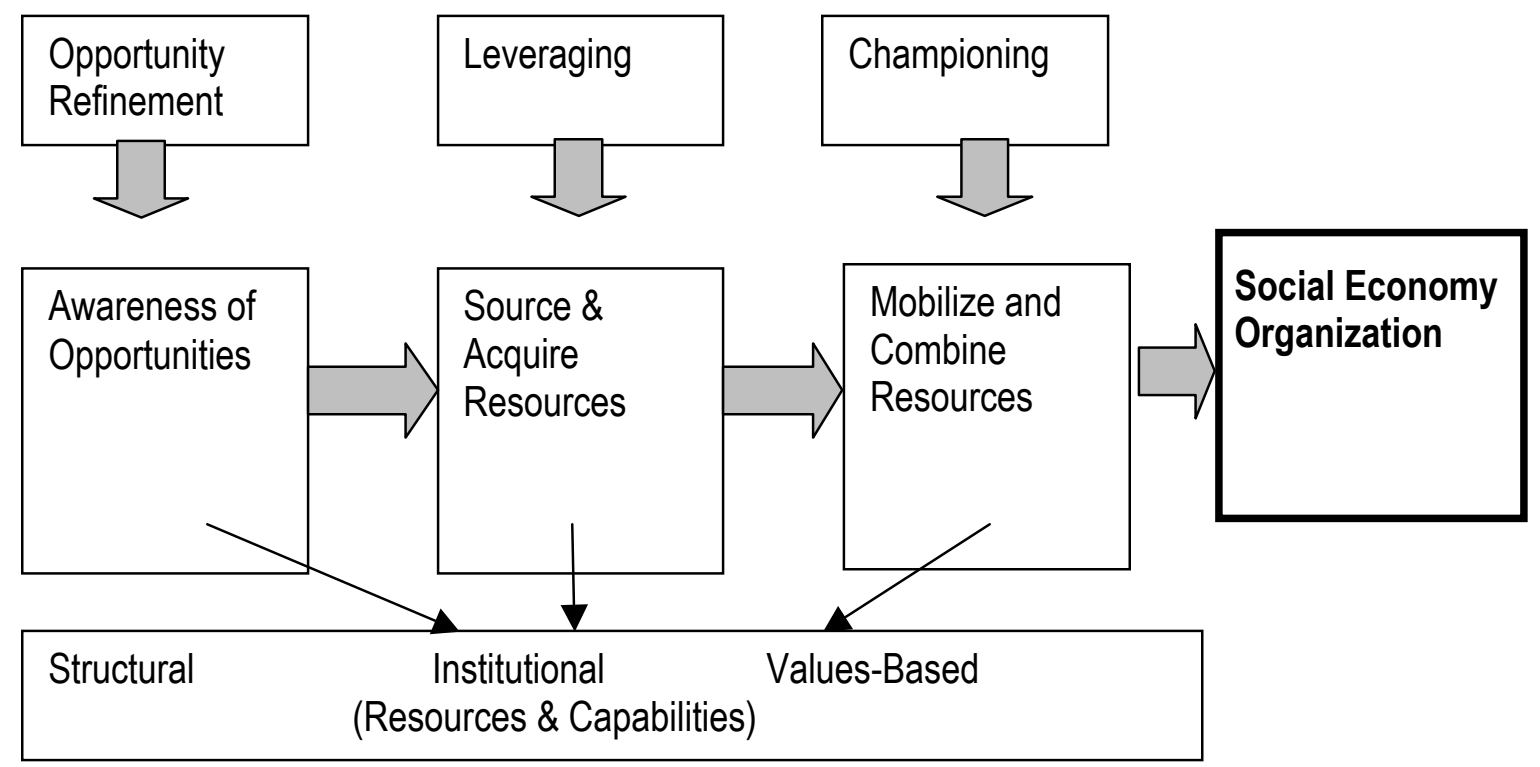




\section{Akingbola (2013)}

\section{METHODOLOGY}

\section{Design and data collection}

This exploratory research (Stebbins, 2001), which was conducted between 2009 and 2010, employed a qualitative methodology supplemented with quantitative data to provide an overview of the characteristics of the organizations. Since most nonprofit social economy organizations in Canada are small (McMullen \& Schellenberg, 2002), and the unincorporated organizations are known to be smaller and informal, this study adapted key informant interviews (Gilchrest \& Williams, 1999) to investigate the context and lived experience of USEOs in Ontario.

To understand the different context of the organizations, this research adopted purposive sampling (Sommer \& Sommer, 1992) of diverse categories of USEOs. The major categories include farmers' markets, hobby groups, food banks, sports clubs, and community associations. It is important to note that many of the groups cannot be found in a directory. This necessitated the use of snowball sampling (Heckathorn, 1997) to reach hidden organizations. Seventy-two social economy organizations agreed to participate in this research, however, only $41(57 \%)$ met the unincorporated criteria and participated in the study. Informants from each USEO participated in semi-structured interviews (Borg \& Gall, 1983) and an online survey. The survey focused on descriptive characteristics and categorical questions on the financial resources, employees, and volunteers of the organizations. A number of the organizations provided secondary data such as a strategic plan, constitution, and by-laws. Table 1 provides an overview of the descriptive characteristics of the organizations, the distribution of the respondents by type of organization, and membership size. Generally, the study sample is representative of the major categories of organizations and groups in the unincorporated social economy in Ontario that are relevant to this study.

The interviews followed a narrative approach (Polkinghorne, 1988). After the interviewer described the research objectives, participants were then asked to explain their involvement in the organization, as well as the background and goals of the organization. Consistent with Rasmussen et al. (2011), the interview process emphasised listening to interviewees with limited interruption and did not use the concept of resources to avoid biases. Broadly speaking, interviews focused on: the goals of the organization, structure, financial resources, human capital, unincorporated status, and growth plans.

Analysis

The interviews were read and reviewed extensively and where necessary, follow up questions were sent to research participants. Demographic data were entered into statistical software to provide simple descriptive statistics. The interviews were analysed extensively to elicit themes that were specific to the research. The entire interview text was combed for descriptive categories, which were then reviewed to highlight themes that were consistent with the theoretical concepts (Orton, 1997). The focus of the data analysis was to elicit narratives provided by the different participants that most illustrate the resources and interactions that support their organizations.

\section{RESOURCE DRIVERS OF UNINCORPORATED SOCIAL ECONOMY ORGANIZATIONS}

One of the objectives of this study was to explain the system-level resources that shape the emergent characteristics of USEOs and how institutional processes and relationships facilitate their adaptive capabilities. If USEOs operate without formal access to resources granted through institutional instruments of society, especially incorporation, what resources support their activities and how do they access such resources. Consistent with Rasmussen et al. (2011), the findings presented below integrate the organizations analyzed by 


\section{Akingbola (2013)}

this research with the relevant scholarly literature. First, the descriptive characteristics of the organizations are presented to provide an overview of the scale, dimension, and operations.

Characteristics of unincorporated social economy organizations

Although USEOs are relatively undefined, the organizations analyzed in this research were similar to incorporated nonprofit organizations in terms of their social mission (Quarter, 1992). The missions of the study organizations are centered on one or more of the following areas: mutual benefit goals; public benefit market goals; non-market social goals; or political interest goals (Bouchard, 2010; Chaves \& Monzón Campos, 2007). Table 1 shows the major characteristics of the study organizations. There are five important conclusions to be drawn from the descriptive characteristics of the USEOs in this study.

First, the unincorporated organizations operate in the economic, social, and political sectors of society (Castells \& Portes, 1989). Many of the organizations are primarily seeking to establish their niche in spaces unoccupied by government, business, or the incorporated nonprofit sector. For example, the mission of USEO Alpha is to provide a market venue for local farmers and craftspeople to sell their produce and products directly to local consumers. Similarly, the mission of USEO Beta is to provide safe haven for people in need in the organization's local community. In some cases, the purpose of the organization is to offer an alternative space to the goals of mainstream organizations. USEO Gamma's mission to fund social enterprises that employ marginalized populations is an example of such a focus.

Second, the majority of the USEOs are very small, both in terms of membership and revenue. Eighteen (53\%) of the organizations have less than 50 members. Although this finding is consistent with the generally small size of nonprofit-type social economy organizations in Canada (McMullen \& Schellenberg, 2002), the relatively high number of the study organizations that have 50 or more members -16 of the 34 organizations that provided membership numbers - appears to indicate a healthy level of participation in these USEOs. Moreover, the findings indicate that most of the organizations have the characteristics of formal organizations. Thirty-three of the participating organizations have a formal organizational structure with executives, while 18 reported that they have a constitution or by-laws.

Third, the USEOs provide a wide-ranging number of products/services and activities to the community and/or to their members. The products/services and activities such as food, weaving, education, and community support are indicative of the diversity of causes in the unincorporated social economy space. Although diverse, the products/services and activities are a by-product of the social mission of each organization. In many of the study organizations with mutual benefit goals, the social mission often transcends the members to the public domain mainly through social network activities and grassroots advocacy. As discussed below, the social networks of the mutual benefit organizations are coopted through the bricolage process.

Fourth, the majority of the organizations - 24 of the 34 that provided information about age - have been operational for more than 10 years. The findings from the descriptive characteristics on size and age of the organizations are particularly important in the analysis of access to resources and capabilities that support and sustain the unincorporated form of organization. On one hand, the small size of the study organizations means that they have fewer resources to draw upon and have limited ability to access resources (Baum \& Singh, 1994; Hager, Galaskiewicz, Bielefeld, \& Pins, 1996; Hager \& Galaskiewicz, 2000; Tucker, Baum, \& Singh, 1992). On the other, the finding that many of the organizations are older - more than 10 years - suggests that they have established some level of social legitimacy and built social networks that could be leveraged to access resources (DiMaggio \& Anheier, 1990). 


\section{Akingbola (2013)}

\section{Table 1: Descriptive Characteristics of Organizations}

*Seven organizations did not provide this information. ${ }^{* *}$ Nine organizations did not provide this information.

\begin{tabular}{|c|c|c|c|c|c|c|}
\hline $\begin{array}{l}\text { Type of Social } \\
\text { Economy }\end{array}$ & $\begin{array}{l}\text { Number } \\
\text { (in } \\
\text { sample) }\end{array}$ & $\begin{array}{l}\text { Types of } \\
\text { Organizations }\end{array}$ & $\begin{array}{l}\text { Number of } \\
\text { Members* }\end{array}$ & Range of Services & Age & $\begin{array}{l}\text { Revenue Last } \\
\text { Fiscal Year** }\end{array}$ \\
\hline $\begin{array}{l}\text { Un-incorporated } \\
\text { non-profit } \\
\text { organization }\end{array}$ & 34 & $\begin{array}{l}\text { Farmers' market, } \\
\text { recreational, union, } \\
\text { advocacy, } \\
\text { neighborhood, } \\
\text { community, cultural, } \\
\text { sports }\end{array}$ & $\begin{array}{c}4 \text { (Up to } 20) \\
10(21-50) \\
2(51-100) \\
6(101-200) \\
6(200+)\end{array}$ & $\begin{array}{l}\text { Food, education, hobby, safe } \\
\text { haven, consultation, } \\
\text { negotiation, sports training, } \\
\text { services for clients with } \\
\text { disabilities, advocacy, forum, } \\
\text { market, local agriculture, } \\
\text { community, networking, } \\
\text { childcare, recreation }\end{array}$ & $\begin{array}{l}4 \text { ( } 40 \text { years }+) \\
5 \text { (31-40 years) } \\
6 \text { ( } 21-30 \text { years) } \\
7 \text { (11-20 years) } \\
9 \text { ( } 1-10 \text { years) }\end{array}$ & Up to $\$ 30,371.19$ \\
\hline $\begin{array}{l}\text { Un-incorporated } \\
\text { for-profit business }\end{array}$ & 3 & $\begin{array}{l}\text { Neighborhood, } \\
\text { community, cultural, } \\
\text { sports }\end{array}$ & $\begin{array}{c}1 \text { (Up to } 20) \\
1(200+)\end{array}$ & $\begin{array}{l}\text { Community-based art, } \\
\text { training }\end{array}$ & 2 (1-5 years) & Up to $\$ 16,000.00$ \\
\hline $\begin{array}{l}\text { Combination of (a) } \\
\text { and (b) }\end{array}$ & 4 & Community, advocacy & $\begin{array}{c}3 \text { (Up to } 20) \\
1(51-100)\end{array}$ & $\begin{array}{l}\text { Community health, children } \\
\text { and parents, membership } \\
\text { support }\end{array}$ & $\begin{array}{l}2 \text { ( } 20-30 \text { years) } \\
1 \text { ( } 1-5 \text { years) }\end{array}$ & $\$ 1210.00$ \\
\hline
\end{tabular}

Opportunity recognition competency

As evidenced from the organizational characteristics, the USEOs in this study have crossed the opportunity recognition (Alvarez \& Busenitz, 2001) phase of their social economy venture. Their missions represent clear articulations of their understanding of mutual or general interest needs. In addition to their missions, other findings provide further evidence of opportunity recognition. For example, USEO Alpha contends that customers come to the farmers' market because they have a serious distrust of corporate agriculture. The customer-base provides an opportunity for the market. USEO Zeta's opportunity was based on the needs of neighbours who wanted to organize around a particular issue such as safety and create a better sense of community. For USEO Eta, opportunity recognition was centered on the need to protect workers' rights through the collective agreement process. Opportunity recognition competency suggests that the USEOs in this study have a key characteristic that is common among social purpose organizations and business entrepreneurs. However, due to a variety of factors, discussed below, they opted to deploy their competencies in the informal sector.

\section{Resources}

For many of the study organizations, their primary resource is derived from their structural characteristic as social economy organizations. Their social mission attract members who identify with the causes and values of the organization. They in turn become the volunteers and core resource of the organization. This resource is manifest in the financial, human, and social capital of each organization.

\section{Financial capital}

Fifty-one percent of the organizations identified membership fees as their main source of revenue (see Table 2). Notwithstanding the unincorporated status of the study organizations, 46 percent indicated that funding from government, foundations, and corporations is also a major source of revenue. This raises a number of questions that are addressed below. The other sources of revenue include sales, fees for services, and donations. The key finding regarding financial resources is that they appear to not be a major driver in these organizations. This is attributable to a number of factors. First, as noted in the descriptive characteristics, the organizations were 


\section{Akingbola (2013)}

established mainly to achieve social objectives. The examples below illustrate the limited emphasis on financial resources.

[USEO Zeta] does offer programming but they try to run it on a non-profit basis. The revenue is almost solely from the programming and this revenue always equals the expenses. In the history of the [USEO Zeta], there have been grants given to the organization. (USEO Zeta Interview Respondent)

Although USEO Eta (a ski club) can generate sales revenue, the question about sales revenue, for example, was deemed irrelevant because according to the respondent the operation of the organization exists on a fine balance.

\section{At USEO Theta:}

In the past, fundraising included bingos, which required reporting to the City. At present, the club is not fundraising. (USEO Theta Interview Respondent)

Second, many of the study organizations are recreational or artistic organizations that offer limited services to the general public. This means that the organizations may be financially self-sufficient through membership fees or the revenue generated through in-kind support. Hence, financial resources are less important. Third, and related to the second factor, twenty-nine $(70 \%)$ of the organizations indicate that financial sustainability is either not a problem, or a small problem. Fourth, the experience of some of the organizations in fundraising could also explain why financial resources are not a major driver. Some of the study organizations report that they tried fundraising, but discovered that they are disadvantaged in the eyes of funding organizations that fund specific types of services. Some of the study organizations explain that they find writing grant application to be overwhelming. A member of USEO Pi, a hand weavers and spinners club noted that: "There aren't very many members who have comfort or knowledge about successfully going through the grant-writing process." Finally, the amount of the financial resources is relatively small. The largest revenue reported for the previous fiscal year was $\$ 30,371.19$ and the combined total revenue of the 32 organizations that provided financial information was $\$ 855,652.00$.

\section{Human capital}

Human capital - knowledge, skills, and capabilities of members - appears to be the USEOs' core resource. Unlike financial capital, human capital permeates the activities and functioning of these organizations. Sixty-five percent of participating organizations indicate that they meet their human resource needs by using volunteers. Twelve organizations (32\%) note that they have employees, while another $10(27 \%)$ have individuals who can be categorized as community volunteers to meet their human resource needs. Four organizations declined to provide this information. Similar to incorporated nonprofits (Akingbola, 2006; Barbeito \& Bowman, 1998; Light, 2003), the skills, knowledge, and behaviour of volunteer members are the most significant resources. Even for the organizations that indicate that employees provide their services, twenty $(98 \%)$ of the groups note that volunteer members are involved in organizational activities. Moreover, the number of employees in the USEOs is small. In many of them, the volunteer members are the only input for the production of outcomes (Akingbola, 2012). For example the respondent from USEO Xi, a naturalist club with 175 members provided this insight: "The current President of the club is the best field naturalist and nature communicator I have ever met. The presidential leadership seems to be a big draw." 


\section{Akingbola (2013)}

USEO $\mathrm{Pi}$, a hand weaver and spinner association, also exemplifies the importance of the human capital volunteer members provide as the core input for organizational outcomes.

Members of USEO Pi meet in the [Community's] Historical Museum. We have an extensive "outreach program" and we make a point of sharing our craft with the community. We teach weaving and spinning to those who express interest; we also teach about our crafts within the school system. [USEO Pi] is asked by teachers to come into the schools and do a small program over the span of an afternoon. (Interview respondent from USEO Pi)

The importance of the human capital provided by volunteer members is also reflected in the financial resources of the study organizations. In some cases, the revenue that supports the activities of the organization is tied to the social legitimacy and human capital of the volunteer members. USEO Kappa, a food bank and USEO Xi, a naturalist club, illustrate this link:

There are so many different sources of revenue for this food bank in particular. It just works. We also have organizational continuity because the President has been in her role for 11 years. (USEO Kappa Interview Respondent)

We generate a tiny bit of cash from sales of publications by ... our president. He gets them at deep discount from his publisher, and we sell them to membership and to the public for profit. (USEO Xi Interview Respondent)

The main type of human capital that supports the activities of the USEOs appears to be the social engagement skills of active volunteer members. This group uses their skill set to keep members together (Seabrook, 1984). Once they are able to acquire the initial social equity - based on the opportunity recognition of the need to solve a mutual or general interest need - the human capital provided by members is combined as the homogeneous input for the organization (Alvarez \& Busenitz, 2001). They leverage this resource to focus on the mission of the organization. Similar to formal social economy and business organizations, the social context of the organization affects how they are able to use resources (Oliver, 1997) to facilitate the mission of the organization. The social context presents opportunities, challenges, and threats to the activities of the USEOs (Baum \& Oliver, 1996; Crittenden, 2000). This inextricably leads to the creation of social capital for the organization.

\section{Social Capital}

The findings suggest that social capital is critical to the operation and survival of the studied USEOs. Many of the USEOs indicate that they use their human capital to build relationships and social networks to support their mission and access or acquire resources such as volunteers and funding. Social capital also includes membership to an umbrella body that is formally incorporated or an affiliate organization that provides access to human capital and systems to support the USEO. Such an organization could provide access to a building, such as a community centre or library for meetings. The following example illustrates the importance of social capital.

Our members spend a lot of time doing relationship-building; in addition, we have a broad network of specialized artist friends who can be recruited for specific types of volunteer work. (Interview respondent, USEO Lambda)

Maintaining the butterfly gardens is very important. Partnering with other organizations for specific projects for education and information is very important. (Interview respondent, USEO Phi) 


\section{Akingbola (2013)}

Money flow is quite small and our liability insurance is gained through our parent organization. ... We have a monthly meeting at a Church; the space is donated for free. The office operates out of a member's home. (Interview respondent, USEO Mu)

Farmers' Markets Ontario is government-funded. They function as a resource but don't necessarily support the financial sustainability and creative funding opportunities for local farmers' markets in Ontario. (Interview respondent, USEO Tau)

In some cases, the social network is used to gain social legitimacy for the USEO.

The level of respect that our organization commands is in part due to the cooperative model upon which it is built. In addition to the volunteer Board of Directors which includes leaders in adult issues and equal representation from all provinces / territories, we have a Professional Advisory Committee [PAC] to which approximately fifteen recognized Canadian experts are appointed. (Interview respondent, USEO Mu)

The evidence on how these organizations use social capital suggests that it is intertwined with human capital. Table 2 illustrates the key resource-base from a sample of study organizations. In the internal environment, USEOs rely on the knowledge, skills, and commitment behaviour of members to sustain organizational operations. In the external environment, USEOs leverage their members' human capital to build social capital, which they then use to access or acquire resources. Importantly, USEOs use both the human and social capital they acquire to champion the mission of the organization, that is, to gain social legitimacy for their mission. Essentially, the evidence indicates that the USEOs are social entrepreneurs who draw on a blend of resources from wherever they can find them to achieve their mission. This type of resource acquisition behavior exemplifies USEOs' members as individual bricoleurs (Di Domenico et al., 2010). They are resourceful in the sense that they are prepared to use whatever strategies are required under a variety of circumstances ( $\mathrm{Di}$ Domenico et al., 2010). This ability to rummage and use available resources is perhaps the leading driver that sustains the activities of these organizations.

Moreover, the findings on how USEOs deploy human and social capital points to the use of entrepreneurial competency that Rasmussen et al. (2011) propose. Once the "opportunity refinement competency" has been enacted by the articulation of the mission, the nascent problem of access to or acquisition of resources is addressed using a combination of approaches. Since many of the USEOs are interest- or hobby-focused, some promote the cause within their micro-community of friends and neighbours before reaching out to the broader community. Other USEOs target all available networks. The two approaches are illustrated below.

USEO Sigma emphasizes the people they know:

In an unincorporated, less constrained environment, knowing your people and understanding their motivations is extremely important but poorly recognized or understood. (Interview respondent, USEO Sigma) 


\section{Akingbola (2013)}

Table 2: Illustration of resource-base

\begin{tabular}{|c|c|c|}
\hline Organization & Resource & Description (Interview Respondents) \\
\hline USEO lota & Human Capital & $\begin{array}{l}\text { Volunteers come and go; some are short-term and some are long-term, but this } \\
\text { does not pose a problem. The organization frequently has a wait-list for } \\
\text { volunteers! }\end{array}$ \\
\hline USEO Kappa & Human Capital & $\begin{array}{l}\text { I just works. We have organizational continuity because the President has been } \\
\text { in her role for } 11 \text { years. }\end{array}$ \\
\hline USEO Lambda & Social Capital & $\begin{array}{l}\text { Participants spend a lot of time doing relationship building; in addition, they } \\
\text { have a broad network of specialized artist friends who can be recruited for } \\
\text { specific types of volunteer work. }\end{array}$ \\
\hline USEO Mu & Social Capital & $\begin{array}{l}\text { The level of respect that the organization commands is in part due to the } \\
\text { cooperative model upon which it is built. In addition to the volunteer Board of } \\
\text { Directors, which includes leaders in adult issues and equal representation from } \\
\text { all provinces/territories, the organization has a Professional Advisory Committee } \\
\text { [PAC] to which approximately fifteen recognized Canadian experts are } \\
\text { appointed. }\end{array}$ \\
\hline USEO Nu & $\begin{array}{l}\text { Social and Human } \\
\text { Capital }\end{array}$ & $\begin{array}{l}\text { We knew that relationship-building was important. Networking is prioritized and } \\
\text { the Executive Director sits on a lot of organizational boards.... We have } 80 \\
\text { volunteers; } 65 \text { of them are for our tutoring program. }\end{array}$ \\
\hline USEO Pi & $\begin{array}{l}\text { Social and Human } \\
\text { Capital }\end{array}$ & $\begin{array}{l}\text { Note that the museum is good to the organization. The museum allows our } \\
\text { organization to go on their insurance, they advertise for us, and they also } \\
\text { charge a reasonable rent. } \\
\text { Most people take a turn in sitting on the Executive or in committee. Some } \\
\text { members are just social members: they can't attend meetings, but they like to } \\
\text { stay involved and attend pot-lucks and picnics. }\end{array}$ \\
\hline USEO Sigma & $\begin{array}{l}\text { Social and Human } \\
\text { Capital }\end{array}$ & $\begin{array}{l}\text { Partnering with other organizations for specific projects is important. } \\
\text { Psychic pay for volunteers: we all operate from a selfish standpoint, but the } \\
\text { 'pay' for volunteering might be feeling good about oneself. When you are } \\
\text { managing people [volunteers or staff] in small organizations, you need to } \\
\text { understand what the 'needs' are for these people. In an unincorporated, less } \\
\text { constrained environment, knowing your people and understanding their } \\
\text { motivations is extremely important but poorly recognized or understood. }\end{array}$ \\
\hline USEO Tau & $\begin{array}{l}\text { Social and Human } \\
\text { Capital }\end{array}$ & $\begin{array}{l}\text { Right now they partner with specific organizations to encourage enthusiasm and } \\
\text { outreach. But it's difficult to anticipate these kinds of spontaneous } \\
\text { collaborations. } \\
\text { The participants believe that volunteering is a key part of engagement with the } \\
\text { social fabric of communities. Somehow or other, there needs to be an active } \\
\text { recognition of the merits and learning opportunities that are derived from } \\
\text { volunteering. Learning to achieve gratification from unexpected places should } \\
\text { be a priority. }\end{array}$ \\
\hline USEO Upsilon & Human Capital & $\begin{array}{l}\text { At times, they bring in other volunteers or pay contract people to do the } \\
\text { naturalization work. The majority of the work that the committee achieves is } \\
\text { done by committee members. }\end{array}$ \\
\hline USEO Phi & Human Capital & $\begin{array}{l}\text { This area is a fairly big retirement community so organizational members are } \\
\text { very skilled and are able to contribute. }\end{array}$ \\
\hline USEO Alpha 2 & Social Capital & $\begin{array}{l}\text { One of the young mothers in the neighbourhood organized to rejuvenate the } \\
\text { small park in the neighbourhood because the equipment was dated. She } \\
\text { organized with the support of our organization to go to the City to organize a } \\
\text { proper rejuvenation. }\end{array}$ \\
\hline
\end{tabular}




\section{Akingbola (2013)}

USEO Sigma emphasizes the people they know:

In an unincorporated, less constrained environment, knowing your people and understanding their motivations is extremely important but poorly recognized or understood. (Interview respondent, USEO Sigma)

USEO Nu targets the broader social network:

Our organization made people a priority and we have built on it every year because we knew we needed to keep it current and we knew that relationship-building was important. Networking is prioritized and the Executive Director sits on a lot of organizational boards. We also have a lot of credibility. (Interview respondent, USEO Nu)

This evidence indicates that the founding members of USEOs use "leveraging competency" to source and acquire the all-important human and social capital to build their social economy venture. To sustain their organization, members use "championing competency" by exercising their bricoleur attributes (Di Domenico et al., 2010). They make do with whatever resources are at hand including those that are not exploited by formal social economy and business organizations to propagate the social economy venture. Although lacking access to resources provided through the institutionalized process of incorporation, they appear to be unconstrained by this limitation (Baker \& Nelson, 2005). For example, USEO Beta 2 received startup funding from a foundation and flourished for some time. After the funding ended, it struggled to achieve sustainability without a long-term source of funding: the organization has managed to survive by pulling resources together.

Incorporation not desirable

Although the question of access to resources is a challenge for any organization, it is evidently more for USEOs because they operate outside the institutionalized system of regulation. However, consistent with Baker and Nelson's (2005) analysis that as part of making do with any available resources, actors in entrepreneurial bricolage "consciously and consistently tested conventional limitations" (p. 335), the study organizations mostly indicate a lack of interest in incorporation. The organizations perceive options that do not involve incorporation or that would side step the regulation as more valuable to meeting their resource challenges. According to USEO Omega, an enterprise foundation, incorporation is not the solution to funding:

Often in the social economy, people who have formed unincorporated organizations think they need to be incorporated when they do not. There are a lot of options and they are growing. The red tape is simpler and less bureaucratic. The disadvantages, of course, are found in accountability. The key is to having a good trustee. There are a number of organizations that have popped up to be those trustees. Being incorporated can take a lot of time away from service provision. (Interview respondent, USEO Omega)

A number of rationales were offered to explain the lack of interest in incorporation. First, for many of the study organizations, incorporation is viewed as an irresponsible use of the limited funds. In this vein, the organizations see incorporation as a means of creating fiscal obligations and onerous reporting requirements. For example, USEO Beta chose to remain unincorporated because members felt the fiscal obligation of incorporation would have been excessive. Second, some of the organizations analyzed the prospect of incorporation from a practical point of view. They contended that since their organizations are small, do not have formal structures, 


\section{Akingbola (2013)}

and have limited membership, incorporation is not warranted. USEO Delta 2 noted that with 289 members and no paid staff or membership fees, there is no need for incorporation. Third, many of the study organizations have networks and umbrella organizations that provide the benefits of incorporation including liability insurance. This significantly reduces their need for incorporation.

Regarding issues around incorporation: so long as the provincial body remains incorporated and can do some of the administrative maintenance and provide insurance ... there really hasn't been a need to incorporate. (USEO Delta 2 Interview Respondent)

Ultimately, the question of incorporation is rooted in the ability of organizations to make do with available resources and extract this to side step the limitation of incorporation (Baker \& Nelson, 2005). They use the resources to overcome the challenges of non-incorporation. From a different perspective, they use their leveraging competency to access and extract the resources provided by the social networks and affiliations of their organizations, to obtain the benefits of incorporation without actually having to do so. As noted above, since most of the USEOs have been active for many years, it is the same leveraging competency that appears to have sustained the activities of the organizations.

\section{DISCUSSION}

USEOs are multidimensional entities. However, since they operate largely below the radar of officialdom, the theoretical and applied context of these organizations are unknown. What do USEOs look like? What are their services and products? What type of resources supports their operations? These are some of the relevant questions that are yet to be explored in the literature, but which are explored in this article. The findings of this study provide evidence that could guide the conceptual mapping of USEOs. First, USEOs are organizations driven foremost by a social mission (Drucker, 1992; Quarter, 1992). The organizations are driven by values shaped by their normative institutional context (Godfrey, 2011), which is translated into the mission developed to achieve mutual and/or general public goals. The diverse activities of the USEOs, including economic activities and specialized hobbies, show the importance of the organizations to the social fabric of the communities.

Second, evidence suggests that USEOs are informal organizations that have opted for noncompliance with the system of institutionalized regulation. The preference for an unincorporated status is based on the regulation and administrative governance entrenched in the incorporation process. Evidence suggests that concerns about administrative regulation are a major factor for the choice to be unincorporated. Essentially, these are organizations established by individuals who want to retain autonomy and control (Godfrey, 2011; Maloney, 1999) over their social purpose venture. However, the organizations have one characteristic that is particularly similar to their formal and small social economy counterparts-they have some form of structure. The structure is important in the ability of organizations to participate in the activities that support their missions.

Third, USEOs access, combine, and leverage two core resources - social and human capital - to support the operations of their organization. The resources are derived primarily from the skills, knowledge, and behaviour of their members. "Behaviour" in the context of this paper, includes the entrepreneurial-like traits and actions that are discussed further below. Members' knowledge and skills are the core inputs that stakeholders combine to create the activities and the performance that support the mutual and / or general interest goals of the organization (Akingbola, 2012; Barbeito \& Bowman, 1998; Light, 2003). Since these organizations do not have elaborate systems, they appear to be shaped more by the competency and interactions of members. The question of competency is evidenced in how members draw upon their social capital to access and leverage resources the organization does not ordinarily have access to due to its unincorporated status. The evidence 


\section{Akingbola (2013)}

that some of the organizations access funding and institutional support through formal social economy and public sector organizations illustrates how they mitigate their inability to access resources and overcome the limitation of their unincorporated status by leveraging social networks. It also highlights how USEOs could be impacted by the vagaries of government funding which has significantly shaped the nonprofit part of the social economy (Akingbola, 2004; Smith \& Lipsky, 1993).

Fourth, evidence indicates that USEOs demonstrate characteristics that are similar to those found in entrepreneurship. First, they follow a process that is similar to entrepreneurial recognition (Alvarez \& Busenitz, 2001). The organizations emphasize an "awareness of opportunities" that is then translated to define their mission. They follow this phase by "sourcing and acquiring the resources needed" to achieve the goals of the organization. Once the social legitimacy of the organization is established in the immediate social network of founding members, USEOs "mobilize and combine" these inputs into the organization's heterogeneous outputs. Second, they appear to draw on whatever resources are at their disposal to support the activities of the organization. This suggests that USEOs are involved in bricolage (Di Domenico et al., 2010; Soteri-Proctor, 2011). The bricoleur attributes of members may explain the longevity of organizations in this study.

\section{CONCLUSION}

This article draws on RBV (Barney, 1991; Wernerfelt, 1984) to examine the characteristics of USEOs, the resources that give rise to and sustain their operations, and any evidence of bricolage in how they acquire resources. Research on the characteristics and practices of such organizations is limited. Due to their informal status and the significant social processes that characterize their activities, research on USEOs logically requires a qualitative approach. As a result, this exploratory study uses empirical data drawn from key contacts and leaders who provide their personal accounts and involvement in the interactions and processes of USEOs (Di Domenico et al., 2010). Qualitative data is supplemented with descriptive statistics to explain the characteristics of the organizations. Hence, the findings provide an important starting point for our understanding of social economy organizations that operate below the radar of legal incorporation. However, there is significant opportunity for future research in this area. This article makes three important contributions to such research.

One, it provides evidence that similar to formally incorporated social economy organizations (Quarter et al., 2009), unincorporated organizations are products of the social mission of their members. Moreover, the evidence suggests that human and social capital are the resources that member acquire and combine to support the activities of the organizations. Specifically, the extent of the importance of social networks could mean that social relationships are more critical to USEOs than their incorporated counterparts. Since USEOs have limited abilities to access resources due to their status, they must build and leverage social networks to acquire the resources they need to support their operations and survive.

Two, by drawing on RBV (Barney, 1991; Wernerfelt, 1984) and applying the concepts of bricolage (Di Domenico et al., 2010), the article provides a theoretical background for future empirical research that may explore organizational behaviour in the informal social economy. Related, is the question of how these theoretical perspectives can be used to explain the interaction between the unincorporated and formally incorporated social economy organizations, especially in terms of resource dependency relationships.

Finally, the article provides exploratory evidence that could guide future research on how core management functions are performed in USEOs. This will inevitably lead to questions about organizational effectiveness and management functions that contribute to the performance of USEOs. For example: what is the relationship 


\section{Akingbola (2013)}

between the extent of coordination and specific human capital practices USEOs adopt? Also, how do the social networks that members draw upon to support the activities of the organization play into the question of organizational effectiveness.

\section{ACKNOWLEDGEMENTS}

I extend thanks to Sonya White, Manuel Larrabure, and Sobia Makhani for their assistance and dedication to this project. I also thank Jack Quarter and the participants for providing information and insights into unincorporated organizations. This research was supported by the Social Sciences and Humanities Research Council.

\section{REFERENCES}

Akingbola, K. (2004). Staffing, retention, and government funding: A case study. Nonprofit Management and Leadership, 14(4): 453-465.

Akingbola, K. (2006). Strategy and HRM in nonprofit organizations: Evidence from Canada. International Journal of Human Resource Management, 17(10), 1707-1725.

Akingbola, K. (2012). A model of strategic nonprofit human resource management. Voluntas: International Journal of Voluntary and Nonprofit Organizations, 1-27.

Alvarez, S., \& Busenitz, L. (2001). The entrepreneurship of resource-based theory. Journal of Management, 27(6), 755-775.

Amit, R., \& Schoemaker, P. (1993). Strategic assets and organizational rent. Strategic Management Journal, 14(1), 33-46.

Baker, T., \& Nelson, R. (2005). Creating something from nothing: Resource construction through entrepreneurial bricolage. Administrative Science Quarterly, 50(3), 329-66.

Barbeito, C., \& Bowman, J. (1998). Nonprofit compensation and benefits practices. New York, NY: Wiley.

Barney, J. (1986). Strategic factor markets: Expectations, luck, and business strategy. Management Science, 32(10), 1231-1241.

Barney, J. (1991). Firm resources and sustained competitive advantage. Journal of Management, 17(99), 99-120.

Barney, J. (1995). Looking inside for competitive advantage. Academy of Management Executive, 9, 49-61.

Baum, J., \& Oliver, C. (1996). Toward an institutional ecology of organizational founding. Academy of Management Journal, 39(5), 1378-1427.

Baum, J., \& Singh, J. (1994). Organizational niches and the dynamics of organizational mortality. American Journal of Sociology, 100(2), 346-380.

Borg, W., \& Gall, M. (1983). Educational research: An introduction. New York, NY: Longman.

Bouchard, M. (2010). Methods and indicators for evaluating the social economy. In M. Bouchard (Ed.), The worth of the social economy: An international perspective. Brussels, Belgium: P.I.E. Lang.

Carroll, G. (1993). A sociological view on why firms differ. Strategic Management Journal, 14(4), 237-249. Castells, M., \& Portes, A. (1989). World underneath: The origins, dynamics, and effects of the informal economy. In A. Portes, M. Castells \& L. Benton (Eds.), The informal economy: Studies in advanced and less developed countries. Baltimore, MD: Johns Hopkins University Press.

Chaves, R., \& Monzón Campos, J. (2007). The social economy in the European union. Brussels, Belgium: International Centre of Research and Information on the Collective Economy (CIRIEC).

Ciborra, C. (1996). The platform organization: Recombining strategies, structures, and surprises. Organization Science, 7(2), 103-118. 
Conner, K. (1991). A historical comparison of resource-based theory and five schools of thought within industrial organization economics: Do we have a new theory of the firm? Journal of Management, 17(1), 121-154.

Crittenden, W. (2000). Spinning straw into gold: The tenuous strategy, funding, and financial performance linkage. Nonprofit and Voluntary Sector Quarterly, 29, 164-182.

Di Domenico, M., Haugh, H., \& Tracey, P. (2010). Social bricolage: Theorizing social value creation in social enterprises. Entrepreneurship Theory and Practice, 34(4), 681-703.

DiMaggio, P., \& Anheier, H. (1990). The sociology of nonprofit organizations and sectors. Annual Review of Sociology, 16, 137-159.

Drucker, P. (1992). Managing the nonprofit organization: Principles and practices. New York, NY: Harper.

Enjorlas, B. (2010). The public policy paradox: normative foundations of social economy and public policies. In M. Bouchard (Ed.), The worth of the social economy: An international perspective. Brussels, Belgium: P.I.E. Lang.

Frumkin, P., \& Andre-Clark, A. (2000). When mission, markets, and politics collide: Values and strategy in the nonprofit human services. Nonprofit and Voluntary Sector Quarterly, 29(1), 141-164.

Gilchrest, V. \& Williams, R. (1990). Key informant interviews. In B. Crabtree, \& W. Miller (Eds.), Doing qualitative research. London, U.K.: Sage.

Godfrey, P. (2011). Toward a theory of the informal economy. The Academy of Management Annals, 5(1), 231-277.

Hager, M., \& Galaskiewicz, J. (2000). A test of ecological, institutional and network determinants of survival among nonprofit organizations. American Sociological Association Annual Meeting, Washington, DC.

Hager, M., Galaskiewicz, J., Bielefeld, W., \& Pins, J. (1996). Tales from the grave: Organizations' account of their own demise. American Behavioral Scientist, 39(8), 975-994.

Hannan, M., \& Freeman, J. (1977). The population ecology of organizations. American Journal of Sociology, 82, 929-964.

Heckathorn, D. (1997). Respondent-driven sampling: A new approach to the study of hidden populations. Social Problems, 2, 174-199.

Herman, R. (2004). The future of nonprofit management. In R. Herman (Ed.), The jossey-bass handbook of nonprofit leadership \& management (2nd ed.). San Francisco, CA: Jossey-Bass.

Jensen, M. \& Meckling, W. (1976). Theory of the firm: Managerial behaviour, agency costs and ownership structure. Journal of Financial Economics, 3(4), 305-360.

Jepperson, R., \& Meyer, J. (1991). The public order and the construction of formal organizations. In W. Powell, \& P. DiMaggio (Eds.), The new institutionalism in organizational analysis. Chicago, IL: University of Chicago Press.

Laville, J., Bélanger, P., Boucher, J., \& Lévesque, B. (Eds.). (1994). L'économie solidaire: Une perspective internationale. Paris, France: Desclée-de-Brouwer.

Levi-Strauss, C. (1968). The savage mind. Chicago, IL: University of Chicago Press.

Light, P. (2003). The health of the human services workforce. Washington, DC: Brookings.

Maloney, W. (1999). Does informality imply segmentation in urban labor markets? Evidence from sectoral transitions in Mexico. The World Bank Economic Review, 13(2), 275-302.

McMullen, K., \& Schellenberg, G. (2002). Mapping the nonprofit sector. Ottawa, ON: Canadian Policy Research Network.

Mook, L., Quarter, J., \& Richmond, B. (2007). What counts: Social accounting for nonprofits and cooperatives. London, U.K.: Sigel Press.

Mook, L., Quarter, J., \& Ryan, S. (Eds.). (2010). Researching the social economy. Toronto, ON: University of Toronto Press.

O'Neill, M. (1998). Nonprofit management education: History, current issues, and the future. In M. O'Neill \& K. Fletcher (Eds.), Nonprofit management education: U.S. and world perspectives. Westport, CT: Praeger.

Oliver, C. (1997). Sustainable competitive advantage: Combining institutional and resource-based views. Strategic Management Journal, 18(9), 697-713. 
Orton, J. (1997). From inductive to iterative grounded theory: Zipping the gap between process theory and process data. Scandinavian Journal of Management, 13(4), 419-438.

Polkinghorne, D. (1988). Narrative knowing and the human sciences. Albany, NY: State University of New York Press.

Quarter, J. (1992). Canada's social economy: Co-operatives, nonprofits and other community enterprises. Toronto, ON: James Lorimer \& Company.

Quarter, J., Mook, L., \& Armstrong, A. (2009). Understanding the social economy: A Canadian perspective. Toronto, ON: University of Toronto Press.

Rasmussen, E., Mosey, S., \& Wright, M. (2011). The evolution of entrepreneurial competencies: A longitudinal study of university spin-off venture emergence. Journal of Management Studies, 48(6), 1314-1345.

Ridder, H., McCandless Baluch, A., \& Piening, E. (2012). The whole is more than the sum of its parts? How HRM is configured in nonprofit organizations and why it matters. Human Resource Management Review, 22(1), 1-14.

Salamon, L., \& Anheier, H. (1998). Social origins of civil society: Explaining the nonprofit sector cross nationally. Voluntas: International Journal of Voluntary and Nonprofit Organizations, 9(3), 213-248.

Schneiberg, M. (2002). Organizational heterogeneity and the production of new forms: Politics, social movements and mutual companies in American fire insurance, 1900-1930. In M. Lounsbury, \& M. Ventresca (Eds.), Social structure and organizations revisited. Bingley, U.K.: JAI Press.

Scott, W. (1987). Organizations: Rational, natural and open systems. Englewood Cliffs, NJ: Prentice Hall.

Seabrook, J. (1984). The idea of neighbourhood: What local politics should be about. London, U.K.: Pluto Press.

Smith, S. \& Lipsky, M. (1993). Nonprofits for hire: The welfare state in the age of contracting. Cambridge, MA: Harvard University Press.

Snell, S. (1999). Social capital and strategic HRM: It's who you know. Human Resource Planning, 22(1), 62-65.

Sommer, B. \& Sommer, R. (1992). A practical guide to behavioral research: Tools and techniques. New York, NY: Oxford University Press.

Soteri-Proctor, A. (2011). Little Big Societies: Micro-mapping of organisations operating below the radar. Paper presented at the Arnova Conference, Toronto, ON.

Stebbins, R. (2001). Exploratory research in the social sciences. Thousand Oaks, CA: Sage.

Stinchcombe, A. (1965). Social structure and organizations. In J. March (Ed.), Handbook of organizations. Chicago, IL: Rand McNally.

Thornhill, S., \& Amit, R. (2003). Learning from failure: Organizational mortality and the resource-based view. Ottawa, ON: Statistics Canada, Analytical Studies Branch.

Tucker, D., Baum, J., \& Singh, J. (1992). The institutional ecology of human service organizations. In Y. Hasenfeld (Ed.), Human services as complex organizations. Newbury Park, CA.: Sage.

Vienney, C. (1994). L'économie sociale. Paris, France : La Découverte, Repères.

Weick, K. (1995). Sensemaking in organizations. Thousand Oaks, CA: Sage.

Wernerfelt, B. (1984). A resource-based view of the firm. Strategic Management Journal, 5(2), 171-180.

Wright, P., \& McMahan, G. (1992). Theoretical perspectives for strategic human resource management. Journal of Management, 18(2), 295-320.

Zahra, S., Gedajlovich, E., Neubaum, D., \& Shulman, J. (2009). A typology of social entrepreneurs: Motives, search processes and ethical challenges. Journal of Business Venturing, 25(5), 519-532.

\section{ABOUT THE AUTHOR / L'AUTEUR}

Kunle Akingbola is Assistant Professor in the Faculty of Business Administration, Lakehead University, Thunder Bay, ON, Canada. Email: kakingbola@lakeheadu.ca 